\title{
Malignant Central Nervous System Mesenchymal, Non-Meningothelial Neoplasm
}

National Cancer Institute

\section{Source}

National Cancer Institute. Malignant Central Nervous System Mesenchymal, NonMeningothelial Neoplasm. NCI Thesaurus. Code C6758.

A metastasizing mesenchymal, non-mening othelial neoplasm that arises from the central nervous system. 